BULLETIN OF POLTAVA
STATE AGRARIAN
$\begin{aligned} & \text { Agriculture. } \\ & \text { Plant growing }\end{aligned}$ ACADEMTI

doi: $10.31210 /$ visnyk2020.04.03

\title{
THE QUALITY OF WINTER WHEAT GRAIN DEPENDING ON SOWING TIME AND FERTILIZATION
}

Ya. V. Astakhova

ORCID (D) 0000-0003-1762-9211

State Institution Institute of Grain Crops of the National Academy of Agrarian Sciences, 14, Volodymyr Vernadskyi Str., Dnipro, 49027, Ukraine

E-mailyana123.astax@gmail.com

How to Cite

Astakhova, Ya. V. (2020). The quality of winter wheat grain depending on sowing time and fertilization. Bulletin of Poltava State Agrarian Academy, (4), 28-34. doi: 10.31210/visnyk2020.04.03

The results of three-year research in the Northern Steppe concerning the influence of sowing time and mineral nutrition on biochemical properties of grain of soft winter wheat varieties (Lastivka Odeska and Holubka Odeska) and hard wheat (Burshtyn) on weed-free fallow and after spring barley are presented in the article. Winter wheat was sown in three periods - September 7, September 22 and October 7. Fertilization variants were the following: 1 - without applying fertilizers (control); 2 - pre-sowing applying fertilizers (on weed-free fallow - $N_{30} P_{60} K_{30}$, after spring barley $-N_{60} P_{60} K_{30}$ ); 3 - fertilization system (against the background of pre-sowing applying mineral fertilizers on weed-free fallow, additional fertilization at the end of plant tillering stage $-N_{30}$ locally, after spring barley $-N_{30}$ on frozen-thawed soil $+N_{30}$ locally). It has been found that in most variants of the experiment a higher content of protein, crude gluten in the grain and better sedimentation indices among the soft wheat varieties were observed in Lastivka Odeska variety. For Lastivka Odeska and Burshtyn varieties, no clear influence of sowing time on these indices was found. As for Holubka Odeska variety, against all fertilization backgrounds after the stubble predecessor, the largest amount of protein and gluten in grain was formed in the early sowing time (September 7). When sowing in the later periods (September 22 and October 7) these indices naturally decreased. It has been revealed that grain of Burshtyn hard winter wheat variety, in contrast to winter soft varieties, contained more protein and gluten in all fertilization variants. On the whole, the amount of protein in Lastivka Odeska varied on weed-free fallow in the range of 11.99-13.58 \%, Holubka Odeska - 11.02-12.62, and in Burshtyn variety - 12.93-14.61\%. After spring barley these indices made 11.47-13.43, 10.68-12.42 and 11.92-14.53\%, respectively. But grain of hard wheat was characterized by low flour sedimentation indices, and gluten was more extensible and weaker than gluten of soft wheat varieties. It has been determined that the maximum values of grain quality indices for all winter wheat varieties were observed at fertilization system, which provided nitrogen additional fertilization of crops in the spring plant vegetation period against the background of pre-sowing application of mineral fertilizers .

Key words: winter wheat, variety, sowing time, fertilization, predecessor, protein, gluten, sedimentation. 


\title{
СІЛЬСЬКЕ ГОСПОДАРСТВО. РОСЛИННИЦТВО
}

\section{ЯКІСТЬ ЗЕРНА ПШЕНИЦІ ОЗИМОЇ ЗАЛЕЖНО ВІД СТРОКІВ СІВБИ ТА УДОБРЕННЯ}

\author{
Я. B. Астахова \\ Державна установа Інститут зернових культур НААН, м. Дніпро, Україна
}

У статті наведено результати трирічних досліджень в умовах Північного Степу щзодо впливу строків сівби мінерального живлення на біохімічні властивості зерна сортів пшениці озимої м'якої (Ластівка одеська та Голубка одеська) і твердої (Бурштин) по чорному пару та після ячменю ярого. Пшениияю озиму висівали у три строки - 7, 22 вересня та 7 жовтня. Варіанти удобрення були такими: 1 - без внесення добрив (контроль); 2 - передпосівне внесення добрив (по чорному пару - $N_{30} P_{60} K_{30,}$ nісля ячменю ярого - $\left.N_{60} P_{60} K_{30}\right) ; 3$ - система удобрення (на фоні передпосівного внесення мінеральних добрив по чорному пару підживлення наприкінці фази кущіння рослин $N_{30}$ локально, після ячменю ярого -

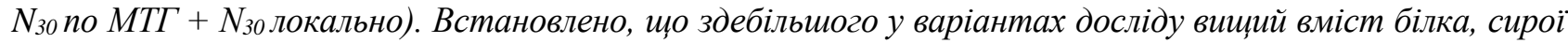
клейковини в зерні та кращзі показники седиментащії серед сортів пшениці м'якої відмічали у сорту Ластівка одеська. Для сортів Ластівка одеська та Буритин не виявлено чітко вираженого впливу строків сівби на ці показники. Для сорту Голубка одеська на всіх фонах живлення після стерньового попередника найбільша кількість білка та клейковини в зерні формувалася у разі раннього строку сівби (7 вересня) та із сівбою в пізніші строки (22 вересня $i 7$ жовтня) вона закономірно зменшувалася. 3'ясовано, щуо зерно пшениці твердої озимої Бурштин на відміну від сортів м'якої містило більше білка та клейковини за всіх варіантів удобрення. Загалом кількість білка в сорту Ластівка одеська варіювала по чорному пару в межах 11,99-13,58 \%, Голубка одеська - 11,02-12,62 \%, а у сорту Бурштин 12,93-14,61\%, після ячменю ярого иіі показники становили відповідно 11,47-13,43 \%, 10,68-12,42 \% та 11,92-14,53\%. Але зерно твердої пшениці характеризувалося низькими значеннями седиментації борошна, а клейковина була більш розтяжною та слабкою порівняно із клейковиною сортів пшениці м'якої. Визначено, щзо максимальні значення показників якості зерна для всіх сортів пшениці озимої відмічали за такої системи удобрення, яка передбачає на фоні передпосівного внесення мінеральних добрив азотні підживлення посівів у весняний період вегетації рослин.

Ключові слова: пшениия озима, сорт, строки сівби, удобрення, попередник, білок, клейковина, седиментація.

\section{Вступ}

Пшениця озима є однією з найважливіших стратегічних сільськогосподарських культур як в Україні, так і у світі. Її зерно використовують для борошномельно-круп’яної, хлібопекарської та комбікормової промисловості. Щоб забезпечити продовольчу безпеку держави, перед аграріями постає питання не тільки збільшення валових зборів зерна пшениці, а й поліпшення його якості. Для розв'язання цих завдань потрібно вдосконалювати технологію вирощування пшениці озимої залежно від попередників, обов’язково зважати при цьому на біологічні особливості їі сортів.

Одним із важливих елементів технології вирощування пшениці озимої є строк сівби. У разі правильно визначеного строку сівби забезпечується добрий розвиток кореневої системи, вузла кущіння та надземної маси рослин [1-4].

Щодо якості зерна, то за даними, наприклад, Г. П. Жемели [5], В. В. Лихочвора [6], а також I. T. Нетіса [7], до зниження вмісту білка та клейковини в зерні призводить сівба пшениці в ранні строки. I навпаки, вміст білка та клейковини в зерні зростає, якщо сівбу пшениці озимої здійснюють в оптимальні й пізні строки, що пояснюється кращим забезпеченням рослин азотом 3 огляду на дещо меншу вегетативну масу.

Доведено, що необхідним заходом підвищення урожайності пшениці озимої та поліпшення якості ii зерна є застосування мінеральних добрив. Суттєве значення мають азотні добрива [8-15], внесення яких навіть за умови вирощування після непарових попередників, дозволяє одержувати продовольче зерно 2-3-го класу якості [16]. На початку вегетації цей захід сприяє підвищенню інтенсивності росту рослин, накопиченню азотних сполук у вегетативних органах, на наступних етапах розвитку пшениці азотні добрива відіграють важливу роль у формуванні зерна.

Загалом, що стосується доз і строків внесення азотних добрив, то серед учених на це питання немає єдиної точки зору. Результати зарубіжних [17] і вітчизняних [18] досліджень свідчать, що засто- 


\section{СІЛЬСЬКЕ ГОСПОДАРСТВО. РОСЛИННИЦТВО}

сування азотних підживлень виправдано у разі низького вмісту цього елементу у грунті, а одноразове внесення високих норм як підживлення (180-240 кг/га) є неефективним [19]. Найбільша віддача від добрив спостерігається у разі низьких норм їх внесення, а по мірі збільшення - віддача на кожен додатково внесений кілограм зменшується [7].

Щоб одержати максимальну врожайність зерна пшениці озимої доброї якості, необхідно одночасно $з$ азотними вносити фосфорні й калійні добрива в оптимальних співвідношеннях [5, 20-25]. Кожен кілограм поживної речовини азотних добрив на фоні фосфорних і калійних сприяє підвищенню вмісту білка в зерні на $0,05 \%$ [26].

Водночас, незважаючи на досить вагомі результати попередніх досліджень, потребує більш глибокого вивчення питання формування якості зерна сучасних сортів пшениці озимої залежно від комплексу технологічних прийомів вирощування в умовах змін клімату, а раніше встановлені рекомендації потребують перегляду та оновлення.

Метою досліджень було з'ясувати особливості формування якості зерна сортів пшениці м'якої та твердої озимої залежно від строків сівби та мінерального живлення по чорному пару та після ячменю ярого в умовах Північного Степу.

Завданням досліджень передбачалося дослідити вплив строків сівби при різних варіантах удобрення посівів на якість зерна сортів пшениці озимої з різними біологічними особливостями.

Матеріали і методи досліджень

Дослідження проводили упродовж 2016-2019 pр. у дослідному господарстві «Дніпро» ДУ Інститут зернових культур, яке відноситься до північної підзони Степу України. Грунтовий покрив дослідних ділянок - чорнозем звичайний малогумусний повнопрофільний. Клімат зони - помірно континентальний, з недостатнім та нестійким зволоженням.

Сіяли пшеницю сівалкою СН-16 суцільним рядковим способом на глибину 5-6 см у триразовій повторності. Ділянки розміщували послідовно систематичним способом. Площа елементарної облікової ділянки 30 м², повторність у досліді - триразова.

Сорти пшениці м'якої озимої Голубка одеська, Ластівка одеська (сильні за якістю зерна) та твердої озимої Бурштин висівали 7, 22 вересня та 7 жовтня після попередників чорний пар та ячмінь ярий. Варіанти підживлень були такими: 1 - без внесення добрив (контроль); 2 - передпосівне внесення добрив (по чорному пару $-\mathrm{N}_{30} \mathrm{P}_{60} \mathrm{~K}_{30}$, після ячменю ярого $-\mathrm{N}_{60} \mathrm{P}_{60} \mathrm{~K}_{30}$ ); 3 - система удобрення (на фоні передпосівного внесення мінеральних добрив по чорному пару підживлення наприкінці фази кущіння рослин $\mathrm{N}_{30}$ локально, після ячменю ярого - $\mathrm{N}_{30}$ по МТГ $+\mathrm{N}_{30}$ локально). Всі спостереження та дослідження проводили відповідно до загальноприйнятих методичних рекомендацій [27-29].

Показники якості зерна визначали за методиками, передбаченими чинними нормативними документами: вміст білка в зерні - на приладі NEOTEC методом інфрачервоної спектроскопії (для калібрування приладу використано значення загального азоту, одержані хімічним методом за К'єльдалем ГОСТ 10846-91), кількість клейковини - шляхом ручного відмивання у воді (ГОСТ 13586.1-68), індекс деформації клейковини - на приладі ВДК-1, число седиментації - згідно із загальноприйнятими методиками 3 використанням 2 \% розчину оцтової кислоти.

\section{Результати досліджень та їх обговорення}

Поживна цінність зерна пшениці, хлібопекарські властивості характеризуються насамперед такими показниками, як вміст білка, кількість та якість клейковини.

За результатами проведених трирічних досліджень було з'ясовано, що в сортів пшениці м'якої озимої Ластівка одеська та Голубка одеська найвищий вміст білка та клейковини в зерні як по чорному пару, так і після ячменю ярого, формувався у варіантах, де на фоні передпосівного внесення мінеральних добрив проводили весняні азотні підживлення. Причому більше білка по чорному пару в цих сортів відмічали у разі оптимального строку сівби (22 вересня), після ячменю ярого таку ж закономірність на фоні без добрив та у разі передпосівного внесення повного добрива мали для сорту Ластівка одеська, а щодо сорту Голубка одеська, та при різних варіантах удобрення кращою білковістю вирізнялося зерно при ранній сівбі (7 вересня). Варто зауважити, що здебільшого після обох попередників за вмістом білка та клейковини в зерні сорт Ластівка одеська переважав сорт Голубка одеська (табл. 1, 2).

3'ясовано, що мінеральне удобрення посівів позитивно впливало на формування вмісту білка та клейковини в зерні пшениці м'якої озимої при всіх строках сівби. Так, у сорту Ластівка одеська кіль- 


\section{СІЛЬСЬКЕ ГОСПОДАРСТВО. РОСЛИННИЦТВО}

кість білка у разі передпосівного внесення комплексного добрива збільшувалася відносно контролю по чорному пару на $0,22-0,45 \%$, після ячменю ярого - на $0,51-1,04 \%$, у сорту Голубка одеська відповідно до попередника на $0,46-0,60$ та $0,38-0,49 \%$. Причому по чорному пару кращу реакцію на таке удобрення спостерігали у сорту Голубка одеська, а після стерньового попередника - у сорту Ластівка одеська.

1. Вміст білка в зерні та число седиментації в різних сортів пшениці озимої залежно від строку сібби та удобрення, в середньому за 2017-2019 рр.

\begin{tabular}{|c|c|c|c|c|c|c|c|}
\hline \multirow{3}{*}{ Сорт } & \multirow{3}{*}{$\begin{array}{l}\text { Строк } \\
\text { сівби }\end{array}$} & \multicolumn{6}{|c|}{ Варіант удобрення } \\
\hline & & \multicolumn{2}{|c|}{$\begin{array}{l}\text { без добрив } \\
\text { (контроль) }\end{array}$} & \multicolumn{2}{|c|}{$\begin{array}{c}\text { передпосівне внесення } \\
\text { добрив* }\end{array}$} & \multicolumn{2}{|c|}{ система удобрення** } \\
\hline & & $\begin{array}{c}\text { вміст білка } \\
\text { в зерні, \% }\end{array}$ & $\begin{array}{l}\text { число седи- } \\
\text { ментації, мл }\end{array}$ & $\begin{array}{l}\text { вміст білка } \\
\text { в зерні, \% }\end{array}$ & $\begin{array}{l}\text { число седи- } \\
\text { ментації, мл }\end{array}$ & \begin{tabular}{|c|} 
вміст білка \\
в зерні, \%
\end{tabular} & $\begin{array}{l}\text { число седи- } \\
\text { ментації, мл }\end{array}$ \\
\hline \multicolumn{8}{|c|}{ Попередник - чорний пар } \\
\hline \multirow{3}{*}{$\begin{array}{l}\text { Ластівка } \\
\text { одеська }\end{array}$} & 7.09 & 11,99 & 38 & 12,35 & 39 & 13,25 & 48 \\
\hline & 22.09 & 12,68 & 41 & 13,13 & 43 & 13,58 & 48 \\
\hline & 7.10 & 12,40 & 42 & 12,62 & 43 & 13,34 & 50 \\
\hline \multirow{3}{*}{$\begin{array}{l}\text { Голубка } \\
\text { одеська }\end{array}$} & 7.09 & 11,02 & 37 & 11,62 & 38 & 12,19 & 44 \\
\hline & 22.09 & 11,21 & 39 & 11,79 & 40 & 12,62 & 44 \\
\hline & 7.10 & 11,07 & 40 & 11,53 & 42 & 12,05 & 43 \\
\hline \multirow{3}{*}{ Бурштин } & 7.09 & 12,93 & 15 & 13,31 & 17 & 14,61 & 18 \\
\hline & 22.09 & 13,42 & 16 & 13,69 & 18 & 14,52 & 20 \\
\hline & 7.10 & 13,36 & 17 & 13,61 & 18 & 14,30 & 20 \\
\hline \multicolumn{8}{|c|}{ Попередник-ячмінь ярий } \\
\hline \multirow{3}{*}{$\begin{array}{l}\text { Ластівка } \\
\text { одеська }\end{array}$} & 7.09 & 11,47 & 37 & 12,51 & 40 & 13,43 & 45 \\
\hline & 22.10 & 11,76 & 38 & 12,76 & 42 & 13,24 & 43 \\
\hline & 7.10 & 11,50 & 39 & 12,01 & 41 & 13,26 & 43 \\
\hline \multirow{3}{*}{$\begin{array}{l}\text { Голубка } \\
\text { одеська }\end{array}$} & 7.09 & 10,93 & 37 & 11,42 & 39 & 12,42 & 42 \\
\hline & 22.09 & 10,85 & 38 & 11,25 & 40 & 12,08 & 41 \\
\hline & 7.10 & 10,68 & 35 & 11,06 & 36 & 11,95 & 37 \\
\hline \multirow{3}{*}{ Бурштин } & 7.09 & 12,69 & 12 & 12,71 & 14 & 14,41 & 17 \\
\hline & 22.09 & 12,19 & 13 & 12,60 & 15 & 13,54 & 18 \\
\hline & 7.10 & 11,92 & 13 & 12,84 & 15 & 14,53 & 17 \\
\hline
\end{tabular}

Примітки: *Норма мінеральних добрив у передпосівне внесення по чорному пару $-\mathrm{N}_{30} \mathrm{P}_{60} \mathrm{~K}_{30}$, після ячменю ярого $-\mathrm{N}_{60} \mathrm{P}_{60} \mathrm{~K}_{30}$; **На фоні передпосівного удобрення по чорному пару наприкінці фази кущіння рослин вносять $\mathrm{N}_{30}$ локально; після ячменю ярого - $\mathrm{N}_{30}$ по МТГ $+\mathrm{N}_{30}$ локально.

Щодо вмісту сирої клейковини в зерні, то аналогічно більший приріст від передпосівного внесення комплексного добрива по чорному пару виявлено у сорту Голубка одеська порівняно з сортом Ластівка одеська, після стерньового попередника - навпаки.

При системі удобрення, яка передбачає на фоні передпосівного внесення комплексного добрива проведення азотних підживлень посівів пшениці озимої (по чорному пару - наприкінці фази кущіння рослин $\mathrm{N}_{30}$ локально, а після ячменю ярого - $\mathrm{N}_{30}$ по МТГ $+\mathrm{N}_{30}$ локально), вміст білка після обох попередників при всіх строках сівби у сорту Ластівка одеська був понад $13 \%$, у сорту Голубка одеська переважно понад 12 \%. Приріст білка по відношенню до контролю для сорту Ластівка одеська по пару варіював у межах $0,90-1,26$, а після ячменю ярого - 1,48-1,96 \%, для сорту Голубка одеська ці показники становили відповідно 0,98-1,41 та 1,23-1,49 \%. 


\section{СІЛЬСЬКЕ ГОСПОДАРСТВО. РОСЛИННИЦТВО}

\section{2. Кількість та якість сирої клейковини в різних сортів пшениці озимої залежно від строку сівби}

та удобрення, в середньому за 2017-2019 рр.

\begin{tabular}{|c|c|c|c|c|c|c|c|}
\hline \multirow{3}{*}{ Сорт } & \multirow{3}{*}{$\begin{array}{l}\text { Строк } \\
\text { сівби }\end{array}$} & \multicolumn{6}{|c|}{ Варіант удобрення } \\
\hline & & \multicolumn{2}{|c|}{$\begin{array}{l}\text { без добрив } \\
\text { (контроль) }\end{array}$} & \multicolumn{2}{|c|}{$\begin{array}{c}\text { передпосівне внесення } \\
\text { добрив* }\end{array}$} & \multicolumn{2}{|c|}{ система удобрення** } \\
\hline & & $\begin{array}{c}\text { вміст } \\
\text { клейковини } \\
\text { в зерні, \% }\end{array}$ & $\begin{array}{c}\text { одиниці } \\
\text { приладу } \\
\text { ВДК-1 }\end{array}$ & $\begin{array}{c}\text { вміст } \\
\text { клейковини } \\
\text { в зерні, \% }\end{array}$ & $\begin{array}{c}\text { одиниці } \\
\text { приладу } \\
\text { ВДК-1 }\end{array}$ & $\begin{array}{c}\text { вміст } \\
\text { клейковини } \\
\text { в зерні, \% }\end{array}$ & $\begin{array}{c}\text { одиниці } \\
\text { приладу } \\
\text { ВДК-1 }\end{array}$ \\
\hline \multicolumn{8}{|c|}{ Попередник - чорний пар } \\
\hline \multirow{3}{*}{$\begin{array}{l}\text { Ластівка } \\
\text { одеська }\end{array}$} & 7.09 & 21,3 & 75 & 22,2 & 73 & 24,5 & 73 \\
\hline & 22.09 & 22,0 & 55 & 23,2 & 65 & 24,1 & 56 \\
\hline & 7.10 & 22,1 & 53 & 23,1 & 50 & 24,8 & 54 \\
\hline \multirow{3}{*}{$\begin{array}{l}\text { Голубка } \\
\text { одеська }\end{array}$} & 7.09 & 19,2 & 63 & 20,7 & 60 & 23,3 & 85 \\
\hline & 22.09 & 19,9 & 55 & 21,8 & 59 & 24,6 & 78 \\
\hline & 7.10 & 20,2 & 60 & 21,6 & 61 & 22,8 & 53 \\
\hline \multirow{3}{*}{ Бурштин } & 7.09 & 22,5 & 97 & 23,5 & 98 & 26,4 & 100 \\
\hline & 22.09 & 22,3 & 97 & 23,8 & 100 & 26,3 & 97 \\
\hline & 7.10 & 22,7 & 98 & 24,6 & 98 & 27,6 & 100 \\
\hline \multicolumn{8}{|c|}{ Попередник - ячмінь ярий } \\
\hline \multirow{3}{*}{$\begin{array}{l}\text { Ластівка } \\
\text { одеська }\end{array}$} & 7.09 & 20,6 & 65 & 23,2 & 67 & 24,3 & 69 \\
\hline & 22.09 & 19,6 & 65 & 22,7 & 58 & 23,4 & 60 \\
\hline & 7.10 & 19,2 & 58 & 21,8 & 65 & 23,5 & 58 \\
\hline \multirow{3}{*}{$\begin{array}{l}\text { Голубка } \\
\text { одеська }\end{array}$} & 7.09 & 18,5 & 65 & 20,2 & 75 & 23,4 & 68 \\
\hline & 22.09 & 17,6 & 63 & 19,6 & 53 & 21,4 & 73 \\
\hline & 7.10 & 16,8 & 57 & 18,7 & 48 & 21,3 & 60 \\
\hline \multirow{3}{*}{ Бурштин } & 7.09 & 21,5 & 98 & 23,6 & 98 & 24,5 & 98 \\
\hline & 22.09 & 20,9 & 97 & 22,5 & 99 & 24,0 & 98 \\
\hline & 7.10 & 20,6 & 100 & 23,2 & 98 & 25,4 & 100 \\
\hline
\end{tabular}

Примітки: *Норма мінеральних добрив у передпосівне внесення по чорному пару $-\mathrm{N}_{30} \mathrm{P}_{60} \mathrm{~K}_{30}$, після ячменю ярого $-\mathrm{N}_{60} \mathrm{P}_{60} \mathrm{~K}_{30}$; **На фоні передпосівного удобрення по чорному пару наприкінці фази кущіння рослин вносять $\mathrm{N}_{30}$ локально; після ячменю ярого - $\mathrm{N}_{30}$ по МТГ $+\mathrm{N}_{30}$ локально.

Відомо, що хлібопекарські властивості пшениці тісно пов'язані з таким показником якості, як седиментація (визначається об'ємом осаду, який утворюється внаслідок змішування борошна зі слабким розчином оцтової або молочної кислоти). Чим більша величина осаду з певної наважки борошна, тим хлібопекарські якості зразка кращі. Виявлено, що у варіантах з максимальним насиченням добрив були й найкращі показники седиментації сортів пшениці м'якої озимої. Так, по чорному пару число седиментації борошна цих сортів змінювалося від 43 до 50 мл, після стерньового попередника від 37 до 45 мл, у контролі (без добрив) значення седиментації були відповідно 37-42 та 35-39 мл.

Встановлено, що зерно пшениці твердої озимої Бурштин на відміну від сортів м'якої містило більше білка та клейковини при всіх варіантах удобрення. Так, у сорту Ластівка одеська кількість білка в зерні по чорному пару варіювала в межах $11,99-13,58$ \%, Голубка одеська - 11,02-12,62 \%, а у сорту Бурштин - 12,93-14,61 \%, після ячменю ярого ці показники становили відповідно 11,47-13,43 \%, 10,68-12,42 \% та 11,92-14,53 \%. Але зерно твердої пшениці характеризувалося низькими значеннями седиментації борошна, а клейковина була більш розтяжною та слабкою порівняно 3 клейковиною сортів пшениці м’якої. Варто зауважити, що внаслідок своїх властивостей зерно твердої пшениці використовується переважно для виготовлення високоякісних макаронних виробів та круп, тоді як м'якої - для вироблення борошна.

Кореляційний аналіз отриманих даних показав, що спостерігалася висока позитивна залежність показників білка та клейковини в зерні різних сортів пшениці озимої, але вона була неоднакової сили. Найбільшим зв'язок між цими двома показниками якості був у сорту Голубка одеська. Як по чорному пару, так і після ячменю ярого коефіцієнт кореляції r для цього сорту становив 0,98 . 


\section{Висновки}

За результатами трирічних досліджень не встановлено чітко вираженого впливу строків сівби на біохімічні показники зерна сортів пшениці озимої Ластівка одеська та Бурштин при вирощуванні в умовах Північного Степу. Водночас для сорту Голубка одеська на всіх фонах живлення після ячменю ярого найбільша кількість білка та клейковини в зерні формувалася у разі раннього строку сівби (7 вересня) та із сівбою в пізніші строки (22 вересня і 7 жовтня) вона закономірно зменшувалася. У сорту пшениці твердої озимої Бурштин на відміну від сортів м'якої формувалося більше білка та клейковини в зерні при всіх варіантах удобрення, але клейковина була більш розтяжною та слабкою, а значення седиментації борошна низькими. Максимальні значення показників якості зерна для всіх сортів пшениці озимої відмічали за такої системи удобрення, яка передбачає на фоні передпосівного внесення мінеральних добрив азотні підживлення посівів у весняний період вегетації рослин.

Перспективи подальших досліджень. Результати проведених досліджень можуть бути використані для оптимізації технологічних прийомів вирощування високоякісного зерна нових сортів пшениці м’якої та твердої озимої в умовах степової зони.

\section{Refences}

1. Gasanova, I. I. (2013). Fundament dlya yakosti. The Ukrainian Farmer, 9. Retrived from: http://www.agrotimes.net/journals/article/fundament-dlya-yakosti [In Ukrainian].

2. Dergachov, O. L. (2010). Vplyv strokiv sivby ta faktoriv mineralnoho zhyvlennia na khlibopekarsku yakist zerna ozymoi pshenytsi. Scientific-Technical. Bulletin of the V. M. Remeslo Myronivka Institute of Wheat, 10, 247-253 [In Ukrainian].

3. Gandjaeva, L. (2019). Effect of sowing date on yield of winter wheat cultivars Grom, Asr and Kuma in Khorezm region. Bulgarian Journal of Agricultural Science, 25 (3), 474-479.

4. Krivenko, A. I., Pochkolina, S. V., \& Bezede, N. G. (2019). Productivity and quality of grain of promising varieties of winter wheat at different sowing periods in the conditions of the southern Steppe of Ukraine. Taurian Scientific Herald, (107), 78-85. doi: 10.32851/2226-0099.2019.107.10

5 Zhemela, G. P., \& Musatov, A. G. (1989). Agrotehnichni osnovi pidvishennya yakosti zerna. Kyiv: Urozhaj [In Ukrainian].

6. Lykhochvor, V. V. (2006). Suchasni intensyvni tekhnolohii vyroshchuvannia osnovnykh polovykh kultur. Lviv: NVF Ukrayinski tekhnolohii [In Ukrainian].

7. Netis, I. T. (2011). Psheniczya ozima na pivdni Ukrayini: monohrafiia. Kherson: Oldi-plyus [In Ukrainian].

8. Lykhochvor, V. V. (2004). Roslynnytstvo. Kyiv [In Ukrainian].

9. Litke, L., \& Gaile, Z. (2018). Effect of nitrogen fertilization on winter wheat yield and yield quality. Agronomy Research, 16 (2), 500-509. doi: 10.15159/AR.18.064

10. Campillo, R., Jobet, C., \& Undurraga, P. (2010). Effects of Nitrogen on Productivity, Grain Quality, and Optimal Nitrogen Rates in Winter Wheat cv. Kumpa-INIA in Andisols of Southern Chile. Chilean Journal of Agricultural Research, 70 (1), 122-131. doi: 10.4067/s0718-58392010000100013

11. Hirzel, J., Matus, I., \& Madariaga, R. (2010). Effect of Split Nitrogen Applications on Durum Wheat Cultivars in Volcanic Soil. Chilean Journal of Agricultural Research, 70 (4), 590-595. doi: 10.4067/s071858392010000400009

12. Zecevic, V., Knezevic, D., Boskovic, J., Micanovic, D., \& Dozet, G. (2010). Effect of nitrogen fertilization on winter wheat quality. Cereal Research Communications, 38, 243-249.

13. Gasanova, I. I., Yerashova, M. V., \& Pedash, O. O. (2019). Vplyv pidzhyvlennia azotom na urozhainist i yakist zerna pshenytsi miakoi ozymoi v pivnichnomu Stepu Ukrainy. Zernovi Kultury, 3 (1), 77-82 [In Ukrainian].

14. Usova, N. M., Solodushko, M. M., \& Romanenko, O. L. (2018). Vplyv poperednykiv ta mineralnoho zhyvlennia na urozhainist i yakist zerna pshenytsi ozymoi. Zernovi Kultury, 2 (2), 281-286 [In Ukrainian].

15. Bilousova, Z. V. (2019). Tekhnolohichni vlastyvosti zerna pshenytsi ozymoi zalezhno vid dii rehuliatora rostu ta rivnia azotnoho zhyvlennia. Taurian Scientific Herald, 110 (1), 19-24. doi: 10.31867/25234544/0037 [In Ukrainian].

16. Gasanova, I. I., Kostirya, I. V., Ostapenko, M. A., Ostapenko, S. M., \& Bondarenko, N. S. (2012). Zakhody pidvyshchennia urozhainosti ta yakosti zerna pshenytsi ozymoi v umovakh Prysyvashshia. Biuleten Institutu Silskoho Hospodarstva Stepovoi Zony NAAN Ukrainy, 2, 98-103 [In Ukrainian]. 
17. Cao, P., Lu, C., \& Yu, Z. (2018). Historical nitrogen fertilizer use in agricultural ecosystems of the contiguous United States during 1850-2015: application rate, timing, and fertilizer types. Earth System Science Data, 10 (2), 969-984. doi: 10.5194/essd-10-969-2018

18. Filonenko, T. A. (2015). Zabezpechenist silskohospodarskykh kultur elementamy zhyvlennia ta yikh urozhainist zalezhno vid zastosuvannia zrostaiuchykh doz azotnykh dobryv. Visnyk Kharkivskoho Natsionalnoho Ahrarnoho Universytetu, 1, 130-137 [In Ukrainian].

19. Gasanova, I. I. Bondarenko, A. S., Poroczka, L. P., \& Girka, A. D. (2006). Vplyv zakhodiv ahrotekhniky na yakist zerna ozymoi pshenytsi v pivnichnomu Stepu. Biuleten Institutu Silskoho Hospodarstva Stepovoi Zony NAAN Ukrainy, 95-98 [In Ukrainian].

20. Kisil, V. I. (2005). Agrokhimichni aspekti ekologizacziyi zemlerobstva. Kharkiv [In Ukrainian].

21. Lisovij, M. V. (2004). Zastosuvannia pidzhyvlennia ozymoi pshenytsi u dva stroky spryiaie pidvyshchenniu urozhainosti i yakosti zerna. Visnyk Kharkivskoho Natsionalnoho Ahrarnoho Universytetu. Serija «Agrokhimiya», 1, 208-211 [In Ukrainian].

22. Golubchenko, V. F., Lisovij, M. V., \& Kulidzhanov, G. A. (2015). Vplyv mineralnykh dobryv na vrozhainist ta yakist zerna pshenytsi ozymoi v roky z riznoiu volohozabezpechenistiu gruntu. Peredgirne ta Girske Zemlerobstvo i Tvarinnicztvo, 58 (1), 51-55 [In Ukrainian].

23. Olkhovskij, G. F. (2002). Ispolzovanie azota nekornevykh podkormok rasteniyami ozimoj psheniczy. Agrokhimiya i gruntoznavstvo. Kharkiv [In Ukrainian].

24. Sidorenko, A. V. (2012). Vliyanie nekornevoj podkormki mikroudobreniyami i karbamidom na kachestvo zerna ozimoj psheniczy $v$ usloviyakh czentralnogo Kryma. Kherson: Ajlant, 57, 68-72 [In Russian].

25. Mostipan, M. I, Shepilova, T. P., \& Kovalov, M. M. (2009). Qualitative indicators of winter wheat grain depending on fertilizers and agrostimulin in the northern steppe of Ukraine. Tavrijskij Naukovyj Visnik, 110, 120-127 doi: 10.32851/2226-0089.2019.110-1.16 [In Ukrainian].

26. Duda, G. G., Druzhchenko, A. V., \& Ivanenko, O. V. (1975). Zalezhnist deiakykh pokaznykiv yakosti zerna ozymoi pshenytsi vid gruntovo-klimatychnykh umov, poperednykiv i udobrennia. Agrokhimiya $i$ Gruntoznavstvo, 30, 29-35 [In Ukrainian].

27. Dospekhov, B. A. (1985). Metodika polevogo opyta s osnovami statisticheskoy obrabotki rezul'tatov issledovaniy (5-th ed. rev.). Moskva: Ahropromizdat [in Russian].

28. Tsikov, V. S., \& Pikush, G. R. (1983). Metodicheskie rekomendacii po provedeniyu polevyh opytov s zernovymi, zernobobovymi i kormovymi kulturami. Dnepropetrovsk [in Russian].

29. Vovkodav, V. V. (2001). Metodika derzhavnogo sortoviprobuvannya s.-g. kultur. Kyiv [In Ukrainian].

Стаття надійшла до редакції 01.10.2020 р.

Бібліографічний опис для цитування:

Астахова Я. В. Якість зерна пшениці озимої залежно від строків сівби та удобрення. Вісник ПДАА. 2020. № 4. C. 28-34.

(C) Астахова Яніна Владиславівна, 2020 